\title{
HOW UNPREJUDICED ARE THE YOUNG?
}

\author{
Volker Meja \\ Brandeis University
}

Prominent pedagogues, journalists, and politicians in the United States, in Germany, and doubtlessly in most other countries subscribe to an image of their youth which astonishes us and suggests hope at the same time: they are said to be skeptical, realistic, tolerant and open-minded; they are said to look for their own standards and to be unprejudiced. The assertion that today's youth do not have any prejudices belongs to journalists and to the indispensable inventory of many speeches on modern youth. "Our youth is indeed largely free of prejudices, as well as the youth of other peoples is free of it today," the German Vice Chancellor, Dr. Erich Mende, stated recently. 1 Rudolf Augstein, editor of the German magazine, DER SPIEGEL, wrote in a similar fashion: "It seems as if prejudice can be found most frequently with the oldest people and least frequently with those born after 1940, and not at all among the students of this age group." 2 Numerous additional examples could be cited, not only for West Germany, but for the United States and other countries.

These opinions about the modern youth, dictated by fancies and perhaps also by political considerations, turn out to be untenable when observed scrupulously. Most relevent psychological and sociological studies, executed in recent years, have shown that negative opinions and discriminatory behavior toward out-groups can be found among young people not less often than among other age-groups. Several examples shall verify this statement.
Donald L. Noel and Alphonso Pikney ${ }^{3}$ collected data from 1,430 white and 805 Negro students in four American cities, using a modified social distance scale as the basic measure of prejudice in their study. The respondents were asked the following questions:

Do you think you would ever find it a little distasteful:

1. to eat at the same table with a white person (Negro)?

2. to dance with a white person (Negro)?

3. to go to a party and find out that most of the people are white (Negro)?

4. to have a white person (Negro) marry someone in your family? ${ }^{4}$

So far as a significant difference between the age-groups is concerned, and this is the only aspect of the study of interest for us here, the authors summarize:

When the respondents are categorized as young (18-34), middle-aged (35-54), and old (55 and over), the overall relationship between age and prejudice is not significant among either Negroes or Whites.' 5

Another American study, related to our problem, by William R. Catton, Jr., and Sung Chick Hong, ${ }^{6}$ includes 557 students at the University of Washington. The authors employed several diff- 
erent methods to test ethnocentrism among the students. Only one part of their study, however, is of interest for us here: the students were provided with a list of 18 minorities ${ }^{7}$ and a social distance scale to fill out.

This scale asked the following questions with regard to each of the eighteen minorities: 1. 'Would you like working beside a member of the following groups?' 2. 'Would you like to have members of any of the following groups go to the same public schools as teenage boys and girls of your own group?' 3. 'Would you like to have members of any of the following groups live in your neighborhood?' 4. 'Now think of all these groups as next-door neighbors. Is there any you would like to have as next-door neighbors?' 5. 'Is there any on the list that, in general, you would like to invite into your home for a social evening?' 6. 'Is there any group in the list that, in general, you would like to have date teenage boys and girls of your own group?' 7. 'Suppose you were thinking of getting married. Is there any on the list that you would be willing to marry?, 8

The mean of the resulting "Social Nearness" scores was computed for each of the eighteen minorities. If we take the ratings for the own group of the respondents as basis and measure its social distance from the other groups we get the following picture: ${ }^{9}$

$\begin{array}{llll}\text { Own group } & 0.00 & \text { Catholic } & 0.88 \\ \text { Swedish } & 0.06 & \text { Jewish } & 1.56 \\ \text { German } & 0.10 & \text { Japanese } & 1.78 \\ \text { Irish } & 0.14 & \text { Chinese } & 1.79 \\ \text { French } & 0.15 & \text { Filipino } & 2.18 \\ \text { Polish } & 0.48 & \text { American Indian } & 2.31 \\ \text { Russian } & 0.50 & \text { Mexican } & 2.63 \\ \text { Italian } & 0.68 & \text { Puerto Rican } & 2.69 \\ \text { Greek } & 0.86 & \text { Negro } & 3.01\end{array}$

According to this study, then, Negroes, Puerto Ricans and Mexicans are the ethnic groups most discriminated against, whereas there is little prejudice against Americans of Swedish, German, Irish and French background.

A German study of the psychologist H. E. Wolf is based upon research with 1300 elementary and high school students in the age-group of 13 to 15 years.10 The students were offered a list with 44 groups, recruited from 4 different circles:
1. national groups, 2. religious-denominational groups, 3. regional and ethnic groups, and 4. complex groups (including Negroes and Jews). ${ }^{11}$ The students were asked to select six of the alphabetically listed groups which appeared to them as especially pleasant or unpleasant; in addition they were asked to attach, with the help of an enclosed list, certain characteristics to the selected groups.

The list of the positively chosen groups is led by "Germans" with $66.1 \%$, "Americans" with $50.4 \%$, and Swiss with $35.5 \%$. The list of the negatively chosen groups is headed by "Russians" with $82.9 \%$, followed by "Jews" with $40.2 \%$ and "Turks" with $38.5 \%$. ${ }^{12}$

Wolf emphasizes that the high and consistent rejection of "Russians," in which neither type of school nor size of town are conspicuous, shows more than mere childlike rejection or even a political opinion. "Russians" are probably largely identified with the mythical notion of the "Communist" and, therefore, occupy the first place in the prejudice scale of young Germans. The least concrete characteristics were given for "Jews" and "Germans." Both the negative choice of the Jews and the positive choice of the own group could not be substantiated; this clearly points to the irrationality of prejudice.

Only those who label the youth with the collective title "unprejudiced" will be astonished about such results. He who is but a little familiar with research in prejudice could expect these conclusions about prejudiced attitudes and corresponding behavior, they have, unfortunately, to be taken as "normal." There is no population class and no age group which is free of prejudices. Therefore, prejudice cannot be fully understood as a matter of irrational individuals but as a phenomenon serving an objective function in our society.

In the face of what in the immediate past has happened with the Jews in Germany, however, and in the face of what is still happening today mainly in 'civilized' countries - with other minority groups, race hatred raises special problems one cannot ignore by a facile referral to the "normality" of prejudiced behavior.

Some time ago an exhibition on the Warsaw Ghetto and its history was presented in Frankfurt, Germany. More than 70,000 people, mostly young people coming with their teachers, visited this exhibition. This gave a good chance to talk 
with young people, to record curious forms of a new kind of antisemitism among this new generation and to observe a pretty general lack of knowledge about how it could come to organized genocide in Germany. Although these interviews cannot be regarded as representative, certain utterances do appear again and again. ${ }^{13}$ Characteristic is the following remark of a white collar worker:

What bothers me with this exhibition is simply that the Germans are presented as that cruel. The pictures are surely very sad; somehow one is touched by it when one sees how people were murdered in masses. It is really tragic... Imean, we feel perhaps guilt, but the others, they certainly must come to hate us. This will never pass by (17 years, female white collar worker).

Typical is the thinking in group categories. As Nietzsche knew: "II did this,' says my memory.' 'I cannot have done this' says my pride, remaining inexorable. Eventually, my memory yields." 14 And when it cannot be denied, then the hatred or malicious joy of others has to serve as an excuse to forget it or to hide it behind euphemistic formulas like the "tragic." Equally dangerous, however, is the opposite attitude. With a light trembling in her voice a high school sophomore confessed:

I am German and have to bear whatmy people have done. I was born in this people and I am responsible for the crimes my forefathers have committed, this seems clear to me. The Jews had to atone for the fact they were born Jews, and we have to atone, for we were born Germans. The only thing we can do... is to implore every Jew on our bended knees to forgive us (15 years, female).

A national collective guilt is assurned with which even children and great-grandchildren are burdened. Who or what really was responsible for the persecutions remains in the dark. Characteristically, this girl believed that the Jews "are somehow completely different" but did not apply this to the abnormal situation they were forced to live in and in which they exactly live ggain in post war Germany. The difference of he Jews is seen as fate or, what is not rare, raced religiously. Curse and blessing, some say, have rested on the "chosen people," thus explaining both its "good" and "bad" characteristic features, the "high intelligence" as well as the "smartness" in business affairs:

Professor Guardini once said to my mother that the Jews are God's own people, and on this people there was a blessing of God and God added a curse to it (15 years, female, German high school student).

In this way the Jewish people's tale of woe, after all that has taken place, is encompassed with the glory of a higher reason: one may refer to it when failing to comprehend what has happened. A kindergarten teacher added:

I have asked myself again and again: why exactly the Jews? I can explain it only from a religious point of view. The Jewish people always had to suffer and still have to suffer today, that (i.e., what happened to them in the Nazi period) was perhaps only another culmination in the sufferings of Israel (10 years, female, German).

The abnormal situation of those Jews still or again living in Germany supplies prejudice with additional nourishment, although this situation is only a consequence of the prevailing prejudice and its result. Jewish fellow citizens and class mates are mentioned, who undeservedly profited from this situation. Some would get restitution pay although nothing happened in their families. For example, a Jewish class mate was sent to the Gymnasium in defiance of bad grades. The whole class was upset, but the teacher explained: "We still have to make so many amends, this must work!' Both teacher and student, reporting this incident, are caught in the vicious circle of prejudice. It is unimportant whether it is colored positively or negatively. With the student it becomes consolidated out of envy, because she herself did not succeed to enter the Gymnasium. Points at which she should blame herself or certain social conditions a substitute object are found and blamed. Resentment is criticism, diverted from the true object. In the history of Western civilization those in power have always managed to make use of the Jews as a downward buffer. They were the victims by which the population could indemnify itself for plagues and famines, and even Hitler expropriated them as 
substitutes for the true principal proprietors.

It is striking that young people consider themselves and their friends as largely unprejudiced, but at the same time give their opinions in a stereotyped manner or recall antisemitic remarks among their friends.

The modern youth, we have a far more comprehensive view, we want a united Europe, a united world, and so on. This first class man, as the German was supposed to be: with blond hair and blue eyes is anyhow balderdash, everybody knows that (17 years, female, apprentice).

The desire for a united Europe, even for a united world, did not prevent this girl from labeling the French as a people "craving for power" and to interpret the discrimination of Italian workers in Germany as justified because of the "bad mentality" of the Italians.

The hatred against Jews, some of them say, is being revived for the reason that they are discoursed upon too frequently:

In our school we have very often lectures on it (i.e., on the history of the 'Third Reich,' antisemitism and concentration camps) and they also show us films from time to time. Finally one asks himself: Why so often? It's really enough when this happens every once in a while, two or three times a year, but why are we bothered with it that often? (18 years, male high school student).

A class mate assists:

The Jew, through the many events being organized, is always shown as a differentbeing, as a being who always calls a certain attention upon him. But the concern people have for a Jew is not of a positive kind, it is always negative, despite everything. It is talked too much about it. Or, to put it quite simply: after a while you get thoroughly sick of it (18 years, male high school student).

These two high school students reflect a widespread sentiment among young Germans. They don't know what to do with documents about recent history, because they fail to understand them. Because they don't understand Jew-hatred and mass murder, because they don't understand their parents who somehow went along with it, they finally look for the reasons within the victims. Thus, we can hear:

There must have been something with the Jews, otherwise they would hardly have been persecuted for more than 2000 years (21 years, male white collar worker).

Repression of guilt works in a similar fashion: the young people are expected to confess the guilt of their own group - the German people with respect to the Jewish minority. This, however, does not harmonize with the positive image one must have of his own group in order to identify with it and to participate in the collective prestige. Guilt cannot be coped with; therefore one asks: who is guilty for this guilt? This, to be sure, mostly turns out to be the victims themselves. Thus, in the most extreme case, the Jews are even blamed for the concentration camps, because they disturb the peace or the youthful impartiality. A rapturous attitude, on the other hand, dictated by bad conscience or admiring curiosity, the pride in a Jewish friend which is common among many young philosemites, is only the other side of the same prejudice. Typical for this philosemitic bias are the remarks of a seventeen-year-old girl:

They are wonderful people, wonderful people. Exactly this high intelligence, and very often this wonderful goodness in them, especially so far as we Germans are concerned (17 years, female high school student).

A young Jew, after having lived in West Germany for more than 5 years, wrote, disillusioned:

Many things may have changed with the German youth-in one respect, however, nothing has changed: in their relations to the Jews... The behavior of non-Jewish young people toward us Jews continuously expresses a certain exculpation which they don't owe us and which to demand we have no right. $^{15}$

Guilt defense and guilt consciousness in the face of a formerly persecuted minority both become a conditioned reflex: one gives a start when suddenly realizing that the interlocutor is 
a Jew. And this only because one identifies with his own group and identifies him with his. One looks for characteristic differences and treats him accordingly. Neither the abnormal situation of the Jews, however, nor the collective guilt complex can seriously be blamed for antisemitic attitudes among young Germans. Prejudice is like a hydra, new and fictitious arguments are continuously formed anew. In psychology they are called "rationalizations" and may assume pathological forms when one, for example, maintains that the Jews are responsible for the defective traffic planning of a city, because they owned all corner-buildings and refused to sell. This, however, is an extreme example. Rationalization presents itself more innocently with young people who are not or only slightly prejudiced, but do not know very much about the nature of prejudice and who, therefore, fall back upon the stereotypes offered by their parents:

The Jews were mostly in high positions, because they were clever, perhaps also cunning, and this most people did not like (20 years, male college student).

Or, another:

Most of the Jews to this time were in business, and almost everybody was at some time deceived a little bit by a Jew. This was spread, and in the course of the time there developed a certain resistance against Jews (19 years, male college student).

Jewish "smartness" in business affairs, at the most, is derived from their medieval circumscription to banking, this again from the Ghetto situation, and so forth. One rationalization produces another, and insight into societal connections remains blocked. Cause and effect are steadily confused. If sometimes the discriminating majority instead of the discriminated minority comes into view then they see only ignorant people, misled by suggested opinions, or simply human nature tending to xenophobia:

I think, it is a human weakness to have to have prejudices (22 years, female college student, German).

Prejudice, as the authors of the Authoritarian
Personality have shown, ${ }^{16}$ is not so much dependent upon the nature of the object as upon the subject's own psychological wants and needs:

The relative ease by which prejudice can be switched from one object to another, point in one direction: the hypothesis thatprejudice, according to its intrinsic content, is but superficially, if at all, related to the specific nature of its object. $^{17}$

Or, as Jean Paul Sartre has put it:

The Jew serves him (i.e. the antisemite) as a pretext; elsewhere his counterpart will make use of the Negro or the man of yellow skin. ${ }^{18}$

It comes as no surprise, therefore, that what has been said about prejudice among young Germans is equally true for young Americans, young Britons, young French. Although there is some anti-semitism in all of these countries, the minority group most obviously discriminated against in some of them, is the Negroes.

An American college student states:

My greatest dislike is against Negroes and I suppose this is because of what I have seen them do to neighborhoods in Kansas City. Whenever they move into an area the property goes down in value. My grandparents were once forced to move because of this (19 years, female college student).

In a similar fashion another girl said:

We live in a low social economic district into which Negro families have slowly begun to filter. Each new family to move across the barrier of a main street is regarded not so much with hatred on race grounds but because the families were lowering the valuation of the property ( 20 years, female college student).

These are again impressive examples that cause and effect can sometimes be completely confused. Obviously the thought never came into the mind of these two students that, after all, not so much the Negroes but the whites may be responsible for this situation. 
But it is not only the connotation of an inferior class position that tends to reduce intimacy between white and colored students. How strong emotional opposition against intermarriage sometimes can be is clearly visible in the following discussion of some female British students: ${ }^{19}$

JUNE (to Miss Webster): Niggers have awful hands - it makes me shudder to think of one touching me. If I had to meet one I should try and avoid all physical contacts with him. I wouldn't dance with one, and I would try not to shake hands. I think I've got a phobia. Not Indians. Their features are different; their noses are thin, and they haven't those big, thick, flabby mouths. I can't bear to think of a nigger kissing me - and his wide, flat nose.

BRENDA: Don't be silly. They're all the same in the dark.

JUNE: Oh no, they're not. You see, sex is a purely animal thing - just physical - so it matters a lot what the physical characteristics of the man are.

SUE (who has also filled in a social distance card): I'm not thinking of the children. I was just considering the physical relationship too, and I couldn't fall in love with one ever.

JUNE: I should like the children.

INTERVIEWER: Would you rather go to bed with an educated Negro in the University, or a white criminal from the London slums?

JENNIE: Neither. I should commit suicide.

JUNE: The white man. I shouldn't worry about his intellect, because sex isn't a mental thing. You're making me feel quite sick when I think of lying beside a nigger and letting him touch me.

A German student commented upon the discrimination of Negroes:

When a man sees another man of a different color he is not exactly repelled; there is, however, a certain feeling appearing with him (20 years, male college student).

Or, an American voice:

I consider it ideal for each race to keep to itself in these more intimate social relationships because the resulting social climate is better for both racial groups involved (19 years, male college student).

This feeling or this social climate is not traced back to social norms and to an education, mediating prejudice, but is hypostatized to a natural fact:

This is simply native to man that he sticks to people of his own race (19 years, male apprentice, German).

I feel it is best for races to refrain from intermarrying or closely fraternizing (such as dating, belonging to the same church group etc.) because conflicts result (19 years, male college student, American).

Or:

One is always more solidaric with the white man than with a black one (20 years, male apprentice, German).

Or:

White and Black are created differently, they are distinct from each other, and one should perhaps better respect this difference (19 years, female nurse, German).

Almost all young people conceived that hatred against Jews and hatred against Negroes are related, despite their different historical development. But practically all of them were unable to point to the nature of this relationship and to answer the question how prejudices come about and why a whole group of people is persecuted:

I cannot say why people had something against the Jews and why today people have something against Negroes. I cannot explain how all this could happen in the past, how this could happen at all. I must be blockheaded or too stupid to explain that, but I simply can't explain it (17 years, male high school student, German).

This totally puzzles me (24 years, female college student, German).

I cannot understand at all why exactly the race of the Jews had to suffer such heavy blows; it could have been the Spaniards or the Portuguese, but why exactly the Jews? Perhaps, because they were chosen by God and therefore... Why in the world was there such a conspiracy against the Jews? (16 years, female apprentice, German). 
Or, two American voices, concerning their attitudes toward Mexicans:

I do seem to have an aversion against Mexicans but I can't explain why (19 years, female college student).

Mexicans do bother me, however the reason is not in my conscious mind. I associate them with greasiness, cunning, cruelty and scheming nature (20 years, male college student).

What reappears with practically all young people is the helpless question for the reasons of persecution and hatred of minorities. They cannot explain it, they are "blockheaded" and "puzzled." Therefore, we can draw the conclusion that the attempts to enlighten them about prejudice and discrimination have not been very successful. Because these efforts did not say very much about the workings of prejudice but only documented its effects, trying to cause a moral reaction, the humanitarian response of saying that "we are all human beings" or even "brothers" remains both abstract and vague, if not supported by the insight into the social mechanisms that stand in the way of humanity and brotherhood. By exhortation or preaching tolerance not much can be accomplished. These sermons don't cost very much and are even being rewarded today. However, even young people believe that prejudice can be most effectively battled with calling upon tolerance:

I think the only thing one can do is to teach the youth tolerance, nothing else (16 years, male apprentice).

Tolerance was extensively taught by the Christian churches and the liberal ideology of the last century without, however, preventing the spreading of antisemitism and race-hatred.

Another illusion lies in the assumption that group prejudice can be dissolved by mere human contact and travel. Personal contact certainly gives knowledge about other people and does away with wrong conceptions. Prejudice, however, is exactly defined by the fact that it cannot be corrected by experience. Personal contact does not preclude prejudice. Sometimes it even serves as an alibi for it:

I have reservations concerning Jews because personal contacts have shown that they discrim- inate against people who are non-Jewish and their moral code is in many cases at odds with my own (23 years, male college student, American).

I have been disgusted with the preoccupation many Jews have with material things... A Jewish rabbi once cheated me out of $\$ 1.23$ by moving from my paper route without paying me or responding to a bill I sent to his new address (19 years, male American college student).

\section{Or:}

I really know many Jews, I have talked with many of them; but nobody can believe how they make fun of us Germans today (17 years, female apprentice, German).

Or, without negative varnish:

I personally know a great many Jews and I have realized that there is something in them which differs widely from us.... There is somehow something curious about them one can't explain (10 years, male high school student, German).

In Germany, social studies, documentary films, exhibitions and books on the persecution of the Jews hardly ever answer the question, urgently asked by young people: Why? Horrorstricken pictures and facts of the German past are, through periodical repetition, brought home to the students. There they remain unconnected and without further explanation until they are made relative, rationalized or repressed. The results are, at best, of a general moral nature: a vague idea that "this must never happen again."

When pedagogical efforts can accomplish something at all, then they should educate about prejudice in such a way that the present scientific knowledge is incorporated. Most of the social and psychological mechanisms, leading to prejudice, have already been studied. It is amazing, therefore, that the results of these studies have hardly obtained access to school instruction and-via the mass media-into the consciousness of the general public. An excellent example of how, instead, even scientists mythologize prejudice is offered in the introduction to "Hitler's Table Talks" by the historian Percy E. Schramm. Professor Schramm writes there: 
We have to be content with the fact that, when analyzing Hitler's antisemitism which exceeded all usual proportions, there will remain a mysterious residue, not open to a rational explanation. ${ }^{20}$

Yet, Hitler himself in Mein Kampf gave this explanation: one needs an anti-type on whom all the evil of this world can be levied, thus presenting his own herd in a more favorable light. Hitler, who admitted his demagogic tricks with remarkable candor, once stated that it would have been necessary to invent "the Jew" if he had not already been there, presenting himself as a victim.

The latent antisemitism of a great part of the German population was a necessary supposition of the murder of the Jews, as every collective hatred may finally find its culmination in mass murder. If it is really true that antisemitism is declining in Germany, then this, as frequently believed, is certainly not due to the fact that there are today hardly any Jews in Germany left. Antisemitism has little to do with the Jews themselves; the sociolgist Theodore W. Adorno once called it the "rumour about the Jews.", 21

In a talk with Hermann Rauschning Hitler voiced a psychological realization when saying: "The Jew is always in us. But it is easier to fight him in bodily form than as invisible demon."22 This mechanism, obviously very familiar to Hitler, is called "projection" in social psychology. The weakness, cowardice and fear one does not dare to admit to oneself is projected. That is why people who are timid themselves tend very often to point out the cowardice of others. People who demand severe persecutions of criminal conduct of others frequently tend themselves to such conduct. Into the Jews and the Negroes exactly those characteristics are "projected" which one recognizes in oneself but has to battle by reason of existing social rules and taboos. The stronger these wishful and instinctual impulses are and the more difficult it becomes to bridle them, the more furious do the attacks against those become who are accused of doing exactly what oneself desires to do. Characterizing the antiSemite, Jean Paul Sartre wrote:

He is a man who is afraid. Not of the Jew, to be sure, but of himself, of his own conscious- ness, of his liberty, of his instincts, of his responsibilities, of solitariness, of change, of society, and of the world - of everything except the Jews. He is a coward who does not want to admit his cowardice to himself; a murderer who represses and censures his tendency to murder without being able to hold it back, yet who dares to kill only in effigy or protected by the anonymity of the mob; a malcontent who dares not revolt from fear of the consequences of his rebellion. ${ }^{23}$

The really fanatic race-hater, be his hatred directed against Jews, Negroes or whatever group, who would like to bring every murdered Jew or Negro to life again in order to murder him anew, tries to kill his own characteristics with the pretended ones of the Negro or the Jew. This shows how irrelevant it is which minority is blamed for all the evil in the world. This was and is, because of peculiar historical reasons, often the Jews, but it may be the Negroes as well as any other ethnic, religious or socio-economic group. Nobody would win anything, however, when the prejudice against Negroes or Jews should be done away with by stigmatizing another minority as the scapegoat.

With the scapegoat theory, based upon the displacement of aggression, we have a second important concept for the explanation of prejudice. In the course of the process of socialization certain disappointments are unavoidable with children. These "frustrations," as they are called in the language of psychology, produce aggressions in the child which are not necessarily harmful. When it is not possible for the child, as is the rule, to direct these aggressions against the original source of the frustrations or to guide them into a harmless channel, then these aggressions are displaced and directed against objects or people who have nothing to do with the original frustrations, that is, against a scapegoat. This, then, is one location of prejudice which appears later with the adult in frightening violence and may lead to the consequences we know. Prejudices are a defect of a personality, unable to gain new experiences; at the same time, however, they are profoundly dangerous for minorities chosen as the object of discrimination.

Whether aggressions are innate or develop in the course of the socialization process - that is, 
produced by society - is a controversial problem. ${ }^{24}$ But even if we assume an innate aggressiveness this could be directed into harmless channels. One might, for example, teach children to give full play to their aggressions without causing damage. They could be given worthless objects to break or destroy; at the same time they could be taught not to destroy valuable objects. One must not show children that certain aggressions are bad without showing at the same time the possibility for a harmless outlet; otherwise the child would look for some channel of his own choice. When combatting prejudice we have to be especially careful that no displacement of the defense mechanism takes place, where prejudice only changes its object.

A third mechanism of prejudice can be characterized as the phenomenon of the "wegroup": all other people are measured according to the standards of the group one identifies with. The supposed characteristics of one's own group are taken as the positive ones; other groups are believed not to have the same positive characteristics, or at least not to the same degree. In this way, collective judgements about whole groups of people come into existence.

The Danish are more parsimonious than the Italians... All Letts steal. All Bulgarians smell. The Rumanians are braver than the French. Russians embezzle money. All this is not truebut it will be heard in the next war.

Each of us could supplement these remarks of Kurt Tucholsky. For instance: In the East Bloc there live monsters; the "free world" is peaceable; Americans are lacking in real culture; Negroes are immoral; this is a Jew; every German is a Nazi, and so on. Such absurd assertions cannot only be heard in a war, we can hear them everywhere even today. Judgements like this, when shared widely, may finally lead to genocide. The murder of a Jew does not start with the construction of the first combustion furnace for a concentration camp; it starts no later than the moment when somebody says: the Jews are the ferment of decomposition.

For prejudiced personalities it is not important what one says and how he behaves; they judge people according to the collectives they belong to. How common these proceedings are can be seen when a foreigner in a country has com- mitted a crime; immediately all members of his group discover that they are outlaws. A press item may illustrate this:

At the weekend hardly an Italian could be found in the restaurants and on the streets of Sindlingen and Zeilsheim. The few Southerners one could see hurried through the streets. They seemed to be deeply worried and alarmed. Therefore they seemingly tried hard not to attract any attention. Even in their homes they talked only in a low voice. Many Italians forewent going out on the weekend. When they could not bear it any longer in their scanty homes they mostly went to the city where they believed they were free of reproachful glances. ${ }^{25}$

Here a whole group is made liable for what was caused by an individual. In a similar way, the Jews have been attached the mark of Cain for more than 2000 years. 2000 years of persecution and pogroms are still today - even among young people-justified with reference to the Jews as having crucified the Savior. A seventeen year old German high school student said:

I find it ridiculous that no minister is any longer allowed to say that the Jews have crucified Christ. It's written in the Bible, isn't it? Isn't it written in the Bible that the Jews have crucified Christ? We do believe in the Bible, don't we? Not an individual person is reproached because of this; people only say: the Jews. Jews is a concept, it has existed, this people existed, always. Jews are Jews, this people has remained the same, we cannot simply rename them. And it is written in the Bible, isn't it? (17 years, female).

Stereotyped opinions about whole groups of people become prejudices which can hardly ever be corrected with adults. Prejudice, however, produces unimaginable discriminations against minority group members: Negroes, Jews, Mexicans, "Communists," etc. Even a national feeling which values people, irrespective of their individuality, according to whether they were born within certain boundary lines and whether they share the same language, prepares the way for aggressive prejudices.

That even critical intellectuals and "valuefree" scientists cannot escape the coercion of 
identification with their own group, may be shown by two examples: The German psychologist, Professor Peter R. Hofstatter, states the fact that no group, no people, no nation can live without an autostereotype which favorably stands out against other groups. He writes:

The specific German problem results from the demand of a constant continuance of the "We." In the face of our recent history it is difficult for us to absorb the documented offences into the wreath of the happy attitudes of the "We." 26

Instead of criticizing this bad "We"-feeling, however, Hofstatter advocates and demands general amnesty for all "war criminals."

The German writer Hans Magnus Enzensberger bemoans that there is no longer such a "we"-feeling among the Germans; nobody can escape, he claims, the question of his own identity. One has to identify collectively, this is self-evident - and "mysterious":

Why there actually are peoples and not simply people, I don't know. But what appears on every bureaucratic form as "citizenship" is older and more stubborn than any bureaucracy, older even and more stubborn than every state. This I know. ${ }^{27}$

Enzensberger mystifies as if it were not possible to exactly determine the psychological mechanisms pushing to collective identification: the weakness of the individual ego and its lack of orientation.

Max Picard, in his book Hitler in Our Selves, showed convincingly how this general ego weakness comes about and to what results it may lead:

During a trip to Germany in 1932, the head of an influential party called upon me to ask how it was possible that Hitler had become so much of a figure and had gained so many followers. I pointed to a magazine which was lying on the table and told him to look at it. Page one was filled by a half-naked dancer; on page two, soldiers were drilling with a machine gun, and farther down a scientist was shown in his laboratory; page three featured the evolution of the bicycle from the middle of the nineteenth century to the present day, and a Chinese poem was printed next to that; the following page was divided between the calisthenics of factory workers during a rest period and the writing technique of a South American Indian tribe by means of knotted strings; on the opposite page, Senator So-and-so was depicted in his summer retreat.

"This," I said, "is how modern man grasps the things of the world outside himself. Modern man drags all things toward himself chaotically and without cohesion; this proves that his own inner life is a chaos lacking cohesion. Modern man no longer confronts the things of the world as solidly existing, nor do things register in his mind individually; neither does he approach a particular thing by a particular act: modern man with his chaotic inner life has a correspondingly chaotic outer world whirling toward him. What is coming is no longer scrutinized; it suffices that anything at all should be coming along. To this disjointed tumult anything or anybody could admix - Adolf Hitler, too: he gets inside a man without his noticing how he got there; from that point on, it no longer depends upon the victim but upon the skill of Adolf Hitler, whether he will merely pass through that man's mind or take hold of it.", 28

It is necessary to discover and understand the mechanisms on which prejudice is based, as it is also important to understand to what degree society makes its appearance. Children reflect the surrounding culture as transmitted to them through their parents, teachers, and friends. Prejudice can only have an effect because society provides people having certain ethnic, racial, or socio-economic characteristics to those who perhaps through even a defective education, are predisposed for prejudice, and who are allowed by society to make use of the minorities offered to them as a target for their aggressions.

Race hatred has its basis in objective societal conditions as well as in the consciousness and unconsciousness of individuals. But it has always been actualized as an instrument of politics; as one of integration of ircompatible groups interests; as the shortest and, for the prejudiced, easiest way to avert themselves from their problems which could be removed in a different way. 
${ }^{1}$ Erich Mende, "Ein familiensoziologisches Problem," in Tribune, 7/63, p. 708, Frankfurt am Main, Germany.

${ }^{2}$ Rudolf Augstein, "Antisemitismus unter uns?," in Der Spiegel, 31/63, p. 32, Hamburg, Germany.

${ }^{3}$ Donald L. Noel and Alphonso Pikney, "Correlates of Prejudice: Some Racial Differences and Similarities," in AJOS, December 1963, pp. 609-622.

${ }^{4}$ Ibid., p. 609.

5 Ibid., p. 613.

${ }^{6}$ William R. Catton, Jr., and Sung Chick Hong, "The Relation of Apparent Minority Ethnocentrism to Majority Antipathy," in American Sociological Review, vol. 27, No. 2 (1962), pp. 178-191. Here quoted after the reprint in Raymond W. Mack, Race, Class, and Power, New York, 1963, pp. 342-357.

7 These 18 groups were: American Indians, Americans of Chinese, Catholic, French, German, Greek, Irish, Italian, Japanese, Jewish, Mexican, Negro, Filipino, Polish, Puerto Rican, Russian, Swedish background, and "Your own group"; Ibid., p. 345 ff.

8 Ibid., p. 346.

${ }^{9}$ Ibid., p. 348 . This is a slightly modified (differently arranged) version of the "Social Nearness" scores as calculated by the authors.

${ }^{10}$ H. E. Wolf, "Vorurteile bei Jugendlichen," in Uberwindung von Vorurteilen, Friedrich-Ebert Stiftung, Bonn, 1960.

11 Ibid., p. 22.

12 Ibid., p. 23.

${ }^{13}$ The data and quotations presented below come from three sources: The quotations of young Germans, 15 to 24 years old, were recorded by the author when interviewing more than 30 students, white- and blue collar workers. Although Negroes as a minority group are referred to, the interviews concentrated on antisemitism. The quotations of American students were taken from 30 questionnaires, returned by students of the University of
Kansas. Although these interviews centered around Negroes, Mexicans and Jews are frequently mentioned. For the purpose of comparison a lengthy quotation was taken from Michael Banton, White and Colored, who interviewed Oxford and Cambridge students about their attitudes concerning intermarriage.

${ }^{14}$ Friedrich Nietzsche, Beyond Good and Evil, Chicago, 1955 , p. 73.

15 Abraham Melzer, "Funf Jahre in Deutschland," in Germania Judaica, No. 5; issue: "Juden in Deutschland heute," pp. $12 \mathrm{ff}$.

${ }^{16}$ T. W. Adorno et. al., The Authoritarian Personality, New York, 1950.

${ }^{17}$ Ibid., p. 612.

18 Jean Paul Sartre, Anti-Semite and Jew, New York, 1962.

${ }^{19}$ Quoted from Michael Banton, White and Colored, New Brunswick, New Jersey, 1960, pp. $140 \mathrm{ff}$.

${ }^{20}$ Quoted after Der Spiege1, 5/64, p. 61.

21 Theodor W. Adorno, Minima Moralia, Frankfurt, 1951, p. 200.

22 Hermann Rauschning, Gesprache mit Hitler, ZurichNew York, 1940, p. 223.

23 J. P. Sartre, Ibid., p. 53.

${ }^{24}$ See Herbert Marcuse, Eros and Civilization, New York, Vintage Books, 1962; also the discussion between Marcuse and Erich Fromm in four issues of Dissent (Summer and Autumn 1955; Winter 1956).

25 "Italienische Landsleute sind bedruckt," in Frankfurter Allgemeine Zeitun', January 20, 1964, p. 11.

${ }^{26}$ P. R. Hofstatter, "Wir Deutschen - wer sind wir?" in Die Zeit, 34/63, p. 9.

${ }^{27}$ H. M. Enzensberger, "Gas penstisch, aber wirklich," in Die Zeit, 63/63, p. 8.

${ }^{28}$ Max Picard, Hitler in Our Selves, Hinsdale, Ill.,1947, pp. 27 ff. 